\title{
Assertiveness and Leadership Styles among Head Nurses
}

\author{
Abeer Mohamed Abdel Wehabe, Samah Faisal Fakhry, Hemat Abd ELazeem Mostafa \\ Nursing Administration Department - Faculty of Nursing, Ain Shams University
}

\begin{abstract}
Background: Assertiveness is important for effective leadership and team building in nursing. Aim: to investigate the relationship between assertiveness and leadership styles among head nurses. Design: analytic cross-sectional. Setting: the study was carried out at Ain-Shams University Hospitals. Sample: It included all available (98) head nurses. Tools: A Selfadministered questionnaire which included two different tools, assertiveness scale and the Multifactor Leadership Questionnaire (MLQ) was used for data collection. Results: The results showed that $77.6 \%$ of head nurses' had a high level of assertiveness, and high percentages were having transformational and transactional leadership, while less than two-fifth were using passive/avoidant leadership style. Significant positive correlations were revealed between the scores of assertiveness and all domains of transformational leadership, and the contingent reward domain of the transactional style, and negative correlations with passive/ avoidant leadership. Significant positive correlations were shown between the scores of assertiveness and all types of leadership outcomes. Conclusion: The study concludes that head nurses in the study settings have a high level of assertiveness. They mostly use the transformational and transactional leadership styles. Meanwhile, the scores of the transformational leadership domains of idealized influence (attributed), idealized influence (behavior), and inspirational motivation have positive effects on their assertiveness, while the laisser-faire leadership has a negative impact on it. Recommendations: The study recommends training courses for head nurses in certain areas of assertiveness and in situational leadership.
\end{abstract}

Key words: Assertiveness, Head Nurses, and Leadership styles.

Introduction

Assertiveness is an interpersonal behavior that promotes quality of human relationships by assisting individuals gives expression to their rights, thoughts and feelings in a manner that neither denies or demeans but recognizes and respects those of others (Cabe and Timmins, 2013). It is a tool for expressing confidently and a way of saying 'yes' or 'no' in an appropriate way (Ellis and Love, 2010). It means expressing personal rights and feelings. Lack of assertiveness can affect one's relationships and quality of life as one fails to communicate effectively and ends up not getting what one wants. It is a learnable skill and mode of communication. Increasing assertiveness can help both personally and professionally (Deena, 2015).

Assertiveness is a state of mind, an attitude, a way of thinking. It is about how interact with others to be a better manager, colleague, or team member. It enables to use behaviors that and other people value (Developing- Assertiveness Traits and Management, 2016). Assertiveness is the art of being confident, and consistently having clear and honest communication while respecting others rights and taking responsibility for one's actions (Arnold and Boggs, 2015). 
Assertiveness is a behavioral response that strives to maintain a balance between passive and aggressive response patterns with a focus on equality and fairness in interpersonal interaction, which is a result of a positive sense of self-respect for others. Assertive behavior requires a high level of differentiation and solid self (DevelopingAssertiveness Traits and Management, 2016).

Assertiveness is a state of mind, an attitude, a way of thinking. It is about how interact with others to be a better manager, colleague, or team member. It enables to use behaviors that and other people value (Developing- Assertiveness Traits and Management, 2016). Assertiveness is the art of being confident, and consistently having clear and honest communication while respecting others rights and taking responsibility for one's actions (Arnold and Boggs, 2015).

Assertiveness is a behavioral response that strives to maintain a balance between passive and aggressive response patterns with a focus on equality and fairness in interpersonal interaction, which is a result of a positive sense of self-respect for others. Assertive behavior requires a high level of differentiation and solid self (DevelopingAssertiveness Traits and Management, 2016).

Leadership is visionary, change-savvy, creative, agile and adaptive. It focuses on achieving nice shiny goals, keeping the team motivated and empowered to achieve as much as they can. It is also about getting the best out of each individual for the benefit of the team. It is about creating the most conducive environment for team success (Rowe, 2014).

Leadership is an art and discipline of guiding, directing, motivating, and inspiring a group or organization toward the achievement of common goals (Marshall,
2011).The style of the nurse leader can be important for employees' acceptance of change and in motivating them to achieve a high quality of care (Azaare \& Gross, 2011). Leaders may use more leadership styles to varying degrees; however, they have a tendency to use characteristics of one style more than the other (Marshall, 2011).

Leadership styles are method of giving direction, motivating people and implementing plans. Researchers believe that as there are many leaders, there are different leadership styles according to the situation. Whatever may be the situation, bad leader on the other hand, tend to use only one style ( Ifezuo 2011) .

\section{Significance of study:}

Assertiveness is important for effective team building in nursing (Yi Cohen, 2012). by being assertive in the right way, leaders can express their legitimate needs, wants, ideas and feelings - and in this way, create honest relationships with others while at the same time also enabling others to respond with their own needs, wants, ideas and feelings.

Nurses often suffer stress and need to be assertive to resist and to cope successfully with work pressure. They need to be assertive in order to be an effective patients' advocate and empower them. Non-assertiveness behavior can lead to stress and poor job satisfaction which leading to poor job retention and high staff turnover. Therefore it is very crucial that nurses are taught and encouraged to be assertive in their practice. Since nurses play vital roles in healthcare organizations, it is important to understand the different leadership styles that are often found in the workplace, as well as its association with their assertive behavior. 
Aim of the study

This study aims to investigate the relationship between assertiveness and leadership styles among head nurses through.(1) Assessing assertiveness of head nurses (2) Assessing Leadership Styles used by head nurses and (3) Examining the relationship between assertiveness and Leadership Styles used by head nurses.

\section{Research question}

1-What is the level of assertiveness among head nurses at Ain shams university hospitals? 2-What are the leadership styles used by head nurses at Ain Shams University hospitals? 3- Is there a relationship between assertiveness and leadership styles used by head nurses at Ain Shams University hospitals?

\section{Subjects and methods}

Design: analytic cross-sectional design.

Setting: This study was conducted at Ain-Shams University Hospitals, which consist of four different hospitals, 1-AinShams University Hospital (Medical) 2- ElDemardash Hospital (Surgical) 3- Pediatrics Hospital 4- Obstetrics Hospital.

Subjects: The subjects of this study included 98 head nurses who work in 4 hospitals of Ain shams university hospitals.. After the exclusion of 5 members who refused to participate in the study.

Sample criteria: The total number of head nurses working at Ain shams university hospitals of the study was 103 . The only inclusion criterion set was having at least a one-year experience in managing the unite. This criterion was fulfilled by all of them so that every one of them was eligible for inclusion in the study sample. However, five head nurses refused to participate in the study, four from El-Demerdash Hospital and one from the Obstetrics Hospital. Therefore, all remaining 98 head nurses were included in the study sample

Sample size: sample size was large enough to identify a correlation coefficient of 0.3 or higher with $80 \%$ power and at a $95 \%$ level of confidence between the scores of assertiveness and leadership, using the Open Epi soft ware package and after accounting for a non-response rate of about $10 \%$.

Sampling technique: Since all available head nurses in the study setting were included in the study, there was no sampling technique to be applied.

Tool of data collection: Two tools used in this study, to collect data namely: assertiveness questionnaire, (Khalil, S. 2014). And multifactor leadership style questionnaire (2004) (MLQ FORM 5X).

\section{Operational design}

The operational design includes the preparatory phase, the pilot study and the fieldwork.

\section{Pilot study}

A pilot study was conducted on ten head nurses from the previously mentioned hospitals, representing $10 \%$ of the study subjects. The aim of pilot study was to test the clarity of language, applicability of the tools, and feasibility of the study. It also estimated the time needed to fill out the questionnaire, which turned to be 20-30 minutes. No modifications were done based on the pilot study, and therefore the pilot subjects were included in the main study sample.

The reliability of the scales was tested in the pilot to confirm reliability of the culture through measuring their internal consistency. They showed a good level of 
reliability, with Cronbach alpha coefficients as shown below.

\section{Tools reliability}

\begin{tabular}{|l|c|c|}
\hline & No of Items & Cronbach'Alpha \\
\hline Assertiveness scale & 47 & 0.883 \\
\hline Leadership scale & 45 & 0.866 \\
\hline
\end{tabular}

\section{Fieldwork}

After the official permission obtained from the director of the four hospitals, the researcher meet the head of each department to determine the suitable time for collecting research data from the study participants. The researcher will meet the participant and explain the aim of the study and ask her / him to fill in the sheets and return it anonymously. The researcher was available for any clarification and checks each sheet after filling for completion of information needed.

\section{Ethical Consideration}

Approval of the study protocol secured from the ethics committee in the faculty of nursing at Ain-shams University. An informed consent was obtained from each participate before collecting any data and after explanation of the study aim in a clear manner .No harmful maneuvers performed or used, and no foreseen hazards are anticipated from conducting the study .participants were informed about their right to refuse or withdraw from the study at any time .Data will be confidential and not used outside this study.

\section{Administrative Design}

Official permission to carry out the study was obtained through a letter addressed from the Dean of the faculty of Nursing. Ain shams university addressed to the manger of the four hospitals. It included an explanation of the purpose of the study as well as data collection form.

\section{Statistical Design}

Data entry and statistical analysis were done using SPSS 20.0 statistical software package. Data were presented using descriptive statistics in the form of frequencies and percentages for qualitative variables, and means and standard deviations and medians and interquartile ranges for quantitative variables. Cronbach alpha coefficient was calculated to assess the reliability of the developed tools through their internal consistency. Qualitative categorical variables were compared using chi-square test. Whenever the expected values in one or more of the cells in a $2 \times 2$ tables was less than 5, Fisher exact test was used instead. In larger than $2 \times 2$ cross-tables, no test could be applied whenever the expected value in $10 \%$ or more of the cells was less than 5. Spearman rank correlation was used for assessment of the interrelationships among quantitative variables and ranked ones. In order to identify the independent predictors of assertiveness and leadership scores multiple linear regression analysis was used, and analysis of variance for the full regression models was done. Statistical significance was considered at $\mathrm{p}$ value $<0.05$. 


\section{Results}

Table 1: socio-demographic characteristics of head nurses in the study sample $(\mathrm{N}=98)$

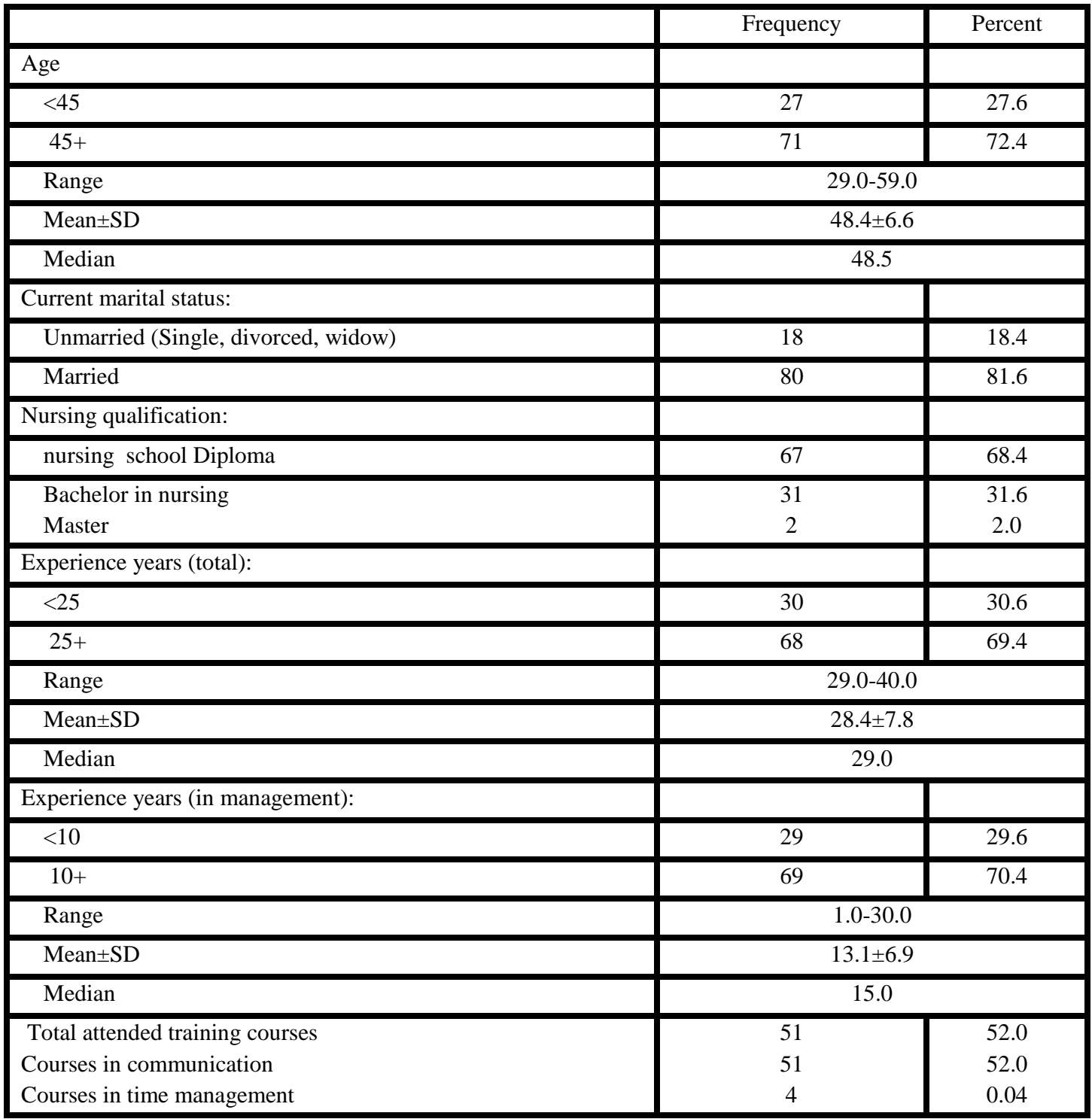

The study sample included 98 head nurses whose age ranged between 29 and 59 years, with median 48.5 years as illustrated in Table 1. The majorities were married (81.6\%) and carried a nursing diploma (68.4\%). Their median total experience was 29.0 years, whereas their median year in management was 15.0. Slightly more than a half of them $(52.0 \%)$ had previously attended training courses in communication. 
Table ( 2 ) : Total assertiveness among head nurses in the study sample (N=98)

\begin{tabular}{|l|c|c|}
\hline High assertiveness (60\%+) in: & Frequency & Percent \\
\hline Verbal and non-verbal style & 62 & 63.3 \\
\hline Active orientation & 93 & 94.9 \\
\hline Work habits & 83 & 84.7 \\
\hline Control of anxiety/fear & 57 & 58.2 \\
\hline Assertiveness Relating to co-workers & 81 & 82.7 \\
\hline Negotiating the system & 89 & 90.8 \\
\hline
\end{tabular}

As illustrated in Table 2, the highest domain of head nurses' assertiveness was that of active orientation (94.9\%) followed by negotiating the system $(90.8 \%)$. At the other extreme, the lowest domains were those of control of anxiety and fear $(58.2 \%)$ and verbal/non-verbal style $(63.3 \%)$.

Figure (1): Total assertiveness style among head nurses in the study sample

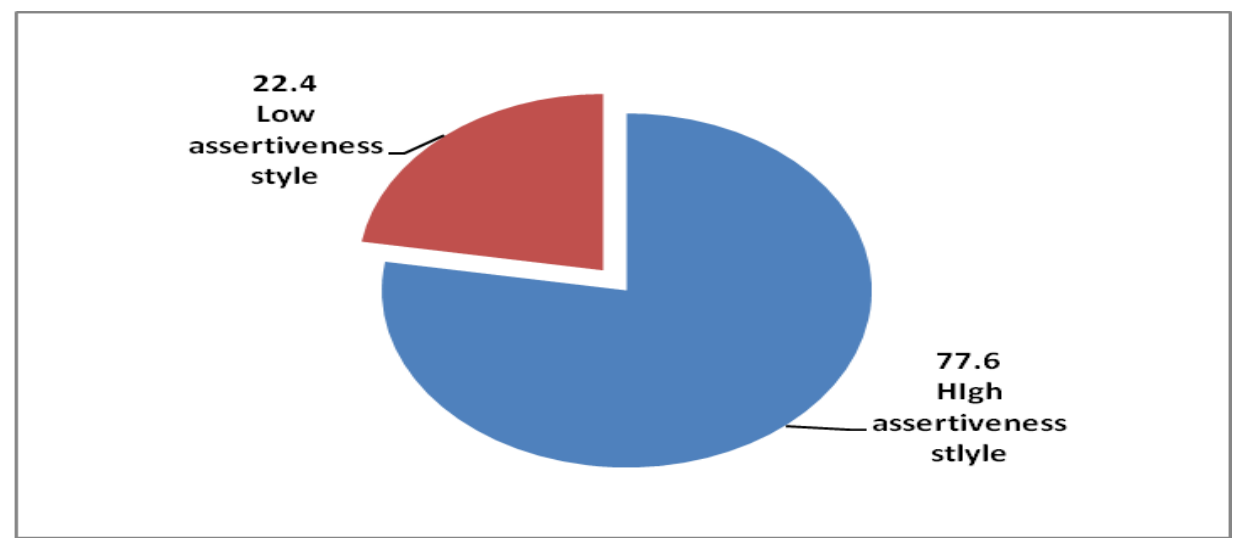

Figure 1 demonstrates that more- than three-fourth (77.6\%) of the head nurses in the study sample were having high level of assertiveness style. 
Table 3: Leadership styles among head nurses in the study sample (N=98)

\begin{tabular}{|c|c|c|c|c|}
\hline \multirow[t]{3}{*}{ Leadership styles } & \multicolumn{4}{|c|}{ Percentile } \\
\hline & \multicolumn{2}{|l|}{$<95^{\text {th }}$} & \multicolumn{2}{|c|}{$95^{\text {th }}+$} \\
\hline & No. & $\%$ & No. & $\%$ \\
\hline \multicolumn{5}{|l|}{ Transformational: } \\
\hline Idealized Influence (Attributed) & 11 & 11.2 & 87 & 88.8 \\
\hline Idealized Influence (Behavior) & 13 & 13.3 & 85 & 86.7 \\
\hline Inspirational Motivation & 19 & 19.4 & 79 & 80.6 \\
\hline Intellectual Stimulation & 10 & 10.2 & 88 & 89.8 \\
\hline Individual Consideration & 14 & 14.3 & 84 & 85.7 \\
\hline \multicolumn{5}{|l|}{ Transactional: } \\
\hline Contingent Reward & 15 & 15.3 & 83 & 84.7 \\
\hline Management-by-Exception (Active) & 9 & 9.2 & 89 & 90.8 \\
\hline \multicolumn{5}{|l|}{ Passive/avoidant: } \\
\hline Management-by-Exception (Passive) & 64 & 65.3 & 34 & 34.7 \\
\hline Laissez-faire Leadership & 59 & 60.2 & 39 & 39.8 \\
\hline
\end{tabular}

As regards leadership styles, Table 3 points to generally high percentages of the head nurses having transformational as well as transactional leadership. The highest style was that of management by exception (active) of the transactional leadership (90.8\%). On the other hand, less than two-fifth of the head nurses were using passive/avoidant leadership style. 
Table 4: Relations between head nurses assertiveness and leadership styles

\begin{tabular}{|c|c|c|c|c|c|c|}
\hline \multirow[t]{3}{*}{ Leadership styles } & \multicolumn{4}{|c|}{ Assertiveness } & \multirow[t]{3}{*}{$\mathrm{X}^{2}$ test } & \multirow[t]{3}{*}{ p-value } \\
\hline & \multicolumn{2}{|c|}{ High } & \multicolumn{2}{|c|}{ Low } & & \\
\hline & No. & $\%$ & No. & $\%$ & & \\
\hline \multicolumn{7}{|l|}{ TRANSFORMATIONAL: } \\
\hline \multicolumn{7}{|l|}{ Idealized Influence (Attributed) } \\
\hline Low $\left(<95^{\text {th }}\right)$ & 3 & 27.3 & 8 & 72.7 & & \\
\hline High $\left(<95^{\text {th }}+\right)$ & 73 & 83.9 & 14 & 16.1 & Fisher & $<0.001^{*}$ \\
\hline \multicolumn{7}{|l|}{ Idealized Influence (Behavior) } \\
\hline $\operatorname{Low}\left(<95^{\text {th }}\right)$ & 3 & 23.1 & 10 & 76.9 & & \\
\hline $\operatorname{High}\left(<95^{\text {th }}+\right)$ & 73 & 85.9 & 12 & 14.1 & Fisher & $<0.001^{*}$ \\
\hline \multicolumn{7}{|l|}{ Inspirational Motivation } \\
\hline Low $\left(<95^{\text {th }}\right)$ & 5 & 26.3 & 14 & 73.7 & & \\
\hline $\operatorname{High}\left(<95^{\text {th }}+\right)$ & 71 & 89.9 & 8 & 10.1 & Fisher & $<0.001^{*}$ \\
\hline \multicolumn{7}{|l|}{ Intellectual Stimulation } \\
\hline Low $\left(<95^{\text {th }}\right)$ & 1 & 10.0 & 9 & 90.0 & & \\
\hline $\operatorname{High}\left(<95^{\text {th }}+\right)$ & 75 & 85.2 & 13 & 14.8 & Fisher & $<0.001^{*}$ \\
\hline \multicolumn{7}{|l|}{ Individual Consideration } \\
\hline Low $\left(<95^{\text {th }}\right)$ & 3 & 21.4 & 11 & 78.6 & & \\
\hline $\operatorname{High}\left(<95^{\text {th }}+\right)$ & 73 & 86.9 & 11 & 13.1 & Fisher & $<0.001^{*}$ \\
\hline \multicolumn{7}{|l|}{ TRANSACTIONAL: } \\
\hline \multicolumn{7}{|l|}{ Contingent Reward } \\
\hline Low $\left(<95^{\text {th }}\right)$ & 4 & 26.7 & 11 & 73.3 & & \\
\hline High $\left(<95^{\text {th }}+\right)$ & 72 & 86.7 & 11 & 13.3 & Fisher & $<0.001^{*}$ \\
\hline \multicolumn{7}{|l|}{ Management-by-Exception (Active) } \\
\hline Low $\left(<95^{\text {th }}\right)$ & 7 & 77.8 & 2 & 22.2 & & \\
\hline $\operatorname{High}\left(<95^{\text {th }}+\right)$ & 69 & 77.5 & 20 & 22.5 & Fisher & 1.00 \\
\hline \multicolumn{7}{|l|}{ PASSIVE/AVOIDANT: } \\
\hline \multicolumn{7}{|l|}{ Management-by-Exception (Passive) } \\
\hline Low $\left(<95^{\text {th }}\right)$ & 57 & 89.1 & 7 & 10.9 & & \\
\hline High $\left(<95^{\text {th }}+\right)$ & 19 & 55.9 & 15 & 44.1 & 14.04 & $<0.001^{*}$ \\
\hline \multicolumn{7}{|l|}{ Laissez-faire Leadership } \\
\hline Low $\left(<95^{\text {th }}\right)$ & 96 & 94.9 & 3 & 5.1 & & \\
\hline $\operatorname{High}\left(<95^{\text {th }}+\right)$ & 20 & 51.3 & 19 & 48.7 & 25.68 & $<0.001^{*}$ \\
\hline
\end{tabular}

(*) Statistically significant at $p<0.001$

As illustrated in Table 4, statistically significant relations were revealed between head nurses' assertiveness and all the domains of transformational leadership $(p<0.001)$, as well as the contingent reward domain of the transactional style $(\mathrm{p}<0.001)$. In all these relations, higher percentages of the head nurses having high leadership were having high assertiveness. Conversely, regarding the passive/avoidant leadership, higher percentages of the head nurses having low such leadership style were having high assertiveness 
Table (5): Leadership outcome among head nurses in the study sample ( $\mathrm{N}=98)$.

\begin{tabular}{|c|c|c|c|c|}
\hline \multirow[t]{3}{*}{ Outcomes of leadership } & \multicolumn{4}{|c|}{ percentile } \\
\hline & \multicolumn{2}{|c|}{$<95^{\text {th }}$} & \multicolumn{2}{|c|}{$95^{\text {th }}$} \\
\hline & No. & $\%$ & No. & $\%$ \\
\hline Extra Effort & 12 & 12.2 & 86 & 87.8 \\
\hline Effectiveness & 14 & 14.3 & 84 & 85.7 \\
\hline satisfaction & 12 & 12.2 & 86 & 87.8 \\
\hline
\end{tabular}

Similarly, Table 5 indicates very high scores for all types of leadership outcomes. This was particularly evident regarding effectiveness, which had a median score 4.75 out of a maximum of 5.00 .

Table (6): Relations between head nurses' assertiveness and leadership outcomes .

\begin{tabular}{|c|c|c|c|c|c|c|}
\hline \multirow[t]{3}{*}{ Leadership outcomes } & \multicolumn{4}{|c|}{ Assertiveness } & \multirow[t]{3}{*}{ Test } & \multirow[t]{3}{*}{ p-value } \\
\hline & \multicolumn{2}{|c|}{ High } & \multicolumn{2}{|c|}{ Low } & & \\
\hline & No & $\%$ & No. & $\%$ & & \\
\hline \multicolumn{7}{|l|}{ Extra Effort } \\
\hline Low $\left(<95^{\text {th }}\right)$ & 3 & 25.0 & 9 & 75.0 & & \\
\hline $\operatorname{High}\left(<95^{\text {th }}+\right)$ & 73 & 84.9 & 13 & 15.1 & Fisher & $<0.001 *$ \\
\hline \multicolumn{7}{|l|}{ Effectiveness } \\
\hline Low $\left(<95^{\text {th }}\right)$ & 4 & 28.6 & 10 & 71.4 & & \\
\hline High $\left(<95^{\text {th }}+\right)$ & 72 & 85.7 & 12 & 14.3 & Fisher & $<0.001^{*}$ \\
\hline \multicolumn{7}{|l|}{ Satisfaction } \\
\hline Low $\left(<95^{\text {th }}\right)$ & 2 & 16.7 & 10 & 83.3 & & \\
\hline $\operatorname{High}\left(<95^{\text {th }}+\right)$ & 74 & 86.0 & 12 & 14.0 & Fisher & $<0.001 *$ \\
\hline
\end{tabular}

* Statistically significant at $\mathrm{P}<0.05$

As regards the relations between head nurses' assertiveness and their leadership outcomes, Table 6 points to statistically significant associations with all types of outcomes $(p<0.001)$. It is evident that higher percentages of the head nurses having high leadership outcomes were having high assertiveness 
Table 7: Correlation between head nurses' assertiveness and leadership scores .

\begin{tabular}{|l|c|l|}
\hline \multirow{2}{*}{\multicolumn{1}{|c|}{ Leadership scores }} & \multicolumn{2}{c|}{ Assertiveness scores } \\
\cline { 2 - 3 } & Spearman's rank correlation coefficient & p-value \\
\hline Transformational & & \\
\hline Idolized influence (attributed) & .501 & $<0.001^{*}$ \\
\hline Idolized influence (Behavior) & .608 & $<0.001^{*}$ \\
\hline Inspirational motivation & .625 & $<0.001^{*}$ \\
\hline Intellectual stimulation & .548 & $<0.001^{*}$ \\
\hline Individual consideration & .410 & $<0.001^{*}$ \\
\hline Transactional: & & $<0.001^{*}$ \\
\hline Contingent reward & .537 & $<0.001^{*}$ \\
\hline Management-by-exception (Active) & .121 & \\
\hline Passive/avoidant: & & $<0.001^{*}$ \\
\hline Management-by-exception (passive) & .223 & $<0.001^{*}$ \\
\hline Laissez-faire leadership & .519 & \\
\hline Outcomes of leadership & & $<0.001^{*}$ \\
\hline Extra effort & .559 & $<0.001^{*}$ \\
\hline Effectiveness & .649 & $<0.001^{*}$ \\
\hline Satisfaction & .650 & \\
\hline
\end{tabular}

* Statistically significant at $\mathrm{P}<0.05$

Table 7 demonstrates statistically significant moderate positive correlations between head nurses' scores of assertiveness and of all domains of transformational leadership, in addition to the contingent reward domain of the transactional style. The strongest of these correlations was between assertiveness and inspirational motivation $(\mathrm{r}=0.625)$. On the other hand, the correlations were negative and weak to moderate between the scores of assertiveness and passive/ avoidant leadership. The table also shows statistically significant moderate positive correlations between head nurses' scores of assertiveness and of all types of leadership outcomes.

Table 8: best fitting multiple linear regression model for the assertiveness score (with leadership scores)

\begin{tabular}{|c|c|c|c|c|c|c|c|}
\hline & \multicolumn{2}{|c|}{$\begin{array}{l}\text { Unstandardized } \\
\text { coefficients }\end{array}$} & \multirow{3}{*}{$\begin{array}{l}\text { Standardized } \\
\text { coefficients }\end{array}$} & \multirow{3}{*}{ t-test } & \multirow{3}{*}{$\begin{array}{c}\mathrm{p}- \\
\text { value }\end{array}$} & \multirow{2}{*}{\multicolumn{2}{|c|}{$\begin{array}{l}95 \% \text { confidence interval for } \\
\text { B }\end{array}$}} \\
\hline & B & Std. Error & & & & & \\
\hline & & & & & & lower & Upper \\
\hline constant & .45 & .16 & & 2.871 & 005 & .140 & .766 \\
\hline $\begin{array}{l}\text { Idealized influence } \\
\text { (Attributed) }\end{array}$ & .09 & 0.4 & .214 & 2.508 & .014 & .019 & .164 \\
\hline $\begin{array}{l}\text { Idealized influence } \\
\text { (Behavior) }\end{array}$ & .09 & .04 & .277 & 2.464 & .016 & .019 & .178 \\
\hline $\begin{array}{c}\text { Inspirational } \\
\text { motivation }\end{array}$ & .09 & .04 & .258 & 2.297 & .024 & .013 & .175 \\
\hline Laisser-faire & .06 & .02 & .207 & 2.743 & .007 & .95 & .015 \\
\hline
\end{tabular}

r-square $=0.15$

Model ANOVA: F=9.56, p<0.001 
Variables entered and excluded: qualification, experience in management, marital status, training courses, hospital

In multivariate analysis (Table 8), the head nurse's total experience years was identified as the main statistically significant independent positive predictor of her assertiveness score. Conversely, her age was a negative predictor. The model, excluding the leadership scores, explains $15 \%$ of the variation in the assertiveness score. None of the other head nurse's characteristics had a significant influence on her assertiveness.

\section{Discussion}

According to the present study findings, more than three-fourth of the head nurses in the study sample were having a high level of assertiveness. This high level of assertiveness might be due to their long experience in nursing (median around 30 years). This is supported by the significant positive correlation between the score of assertiveness and the total years of experience. Moreover, the total experience years turned to be a positive independent predictor of the assertiveness score in multivariate analysis. The finding agrees with Shaker and Khalil (2014) who showed that the majority of the nurse managers working at Ain-Shams university hospitals were assertive. Similar findings were also reported in the study of Abdel-Aleem (2007) in Suez Canal University hospitals.

The present study results demonstrated that the head nurses' assertiveness was highest in the domain of active orientation. All its items had high scores of agreement. However, although almost all of them agreed upon the item of loving the work they do, only approximately two thirds of them expressed their agreement upon the item of suggesting new procedure and ideas. This reflects the widespread problem of lack of active participation of nurses in decisionmaking in health care settings, yet they like their work. The importance of assertiveness in proper decision-making was demonstrated in a study on registered nurses in Sweden (Melin-Johansson et al, 2017).

The second highest domain of assertiveness among the nurse managers in the present study was that of negotiating the system. Their agreement was high upon all its items. This reflects high abilities of discussing decisions without embarrassment and cooperating with others. These are certainly acquired by experience, particularly that these head nurses have long experience in management with median around 15 years. The value of training in assertiveness in enhancing the negotiation skills was demonstrated in a study on undergraduate midwifery students in Australia (Warland et al, 2014).

As regards head nurses' assertiveness in the domain of relating to co-workers, the current study findings showed high percentages of agreement upon most items. The only exception was concerning the item of saying no to others if necessary. This might be explained on cultural backgrounds in the Egyptian society, where people tend to refrain from saying "No" just to please others even at own expense. In congruence with this, a study carried out in the United States reported that nurses attributed their lack of assertive behaviors of speaking-up to concerns about relationships with peers (Reese et al, 2016).

The age of the head nurses in the current study had a significant positive correlation with their scores of assertiveness. This was also confirmed in multivariate analysis. The relation could be explained by the generation differences, where the new generations tend to be more assertive given the changes in the educational systems as well as in the society norms. In agreement with this, a study in Croatia Stojčić et al (2014) found an inverse relationship between 
nurses' age and their level of assertiveness. Moreover, Foley et al (2012), in a study in Canada, analyzed the generation differences and associated problems. They recommended proactive measures to inspire the future generation of nurses, rather than stifling their spirit and assertiveness.

Conversely, the current study results demonstrated that a significant positive correlation between head nurses' total experience years and their scores of assertiveness. The finding was further supported by multivariate analysis, where the total experience years was identified as the main significant positive predictor of the assertiveness score. This is quite conceivable since the longer years of work accumulate experience and expertise, which could enhance head nurses' assertiveness. A similar association was revealed in a study addressing assertive communication among nurses and physicians in San Francisco (Lyndon et al, 2012). On the same line, studies in Egypt reported significant relations between assertiveness and nursing years of experience (Abdel-Khalek, 2010; Khalil, 2011).

It was also found that the head nurses having a diploma degree were more assertive when compared to those having a bachelor degree in nursing. This was also revealed in correlation analysis. This might be explained by the longer experience and the higher seniority and work privileges among the diploma nurses. However, this was not found in multivariate analysis, which may indicate that the influence of qualification was confounded by age and years of experience. Nevertheless, the relation between the level of nursing qualifications and assertiveness are still under study (Green, 2016).

The present study assessed head nurses' leadership styles. The results demonstrated that the transformational leadership style was the most commonly used. Its idealized influence (behavior) component had the highest score. The finding is in agreement with the results reported by Ross et al (2014) in a study of nurse leaders in professional nursing associations in the United States, where the majority were using this leadership style. A similar finding was revealed in a study in Belgium (Lievens and Vlerick, 2014); additionally, the authors found that the use of transformational leadership enhanced nurses' safety performance. On the same line, a study in Taiwan showed a high use of the transformational leadership style among nurse leaders, and this was associated with enhancement of nurses' innovative behavior (Weng et al, 2015).

As regards to the transactional leadership, the present study showed that its management by exception (active) component was used by a great majority of the present study head nurses. The finding is in agreement with the results of a study carried out in Italy, which found that the nurse managers mostly used a transactional leadership style (Management by exception active') aimed at monitoring errors and intervening to correct errors and punish (Morsiani et al, 2017). On the same line, in a study in the United Arab Emirates, nurse leaders were found to be using the transactional leadership style as well as the transformational style in different combinations (El Amouri and O'Neill, 2014). A similar finding was also reported by Alshahrani and Baig (2016) in a study in the Kingdom of Saudi Arabia

The current study findings have also demonstrated that the passive/avoidant leadership style was the least used by head nurses. Only approximately two-fifth of them was using it. The finding is in agreement with a study conducted in Spain on primary health care managers (Jodar et al, 2016). The participants predominantly used the transactional and transformational leadership styles, with much less use of the laissez-faire style Furthermore, the present study findings pointed highly leadership outcomes, 
especially for extra-effort and satisfaction. This is quite expected given that most of the head nurses are using positive styles of leadership, namely transformational and transactional styles. The importance of such outcomes both for the nurses and the patients' benefits were highlighted in a study in Iran, which addressed the ethical aspects of leadership (Barkhordari- Sharifabad et al, 2017).

An association similar to the foregoing present study one was claimed by GøtzscheAstrup et al (2016) in a study in Norway; however, the authors suggested that assertiveness does predict the leadership style. On the same line, Hsin-Yi Cohen (2012) clarified that a good leader should know how to use assertiveness to gain respect and authority, without alienating any members of the group or anyone outside the group.

Concerning the transactional leadership style and its relation with assertiveness, the current study results indicated that significantly more head nurses with high assertiveness were using the contingent reward domain of this style. This was also shown in correlation analysis. However, the relation was not revealed in multivariate analysis, which would question the authenticity of this relationship. Nonetheless, the relation between assertiveness and transactional leadership has been previously addressed (Weiss and Tappe, 2014)

. The current study findings have also revealed significant relationships between head nurses' leadership outcomes and their assertiveness. Thus, positive correlations were found between the scores of assertiveness and all types of leadership outcomes. In congruence with this, Ames (2009) mentioned the presence of an association between assertiveness and the effectiveness outcome of leadership.

As regards the factors related to head nurses' use of the various leadership styles, the current study demonstrated significant negative correlations between the level of nursing qualifications and the scores of all domains of transformational leadership, and the contingent reward domain of the transactional style. On the other hand, a positive correlation was identified between the laisser-faire leadership score and the level of nursing qualification. This means that the diploma head nurses tend to use more positive leadership styles in comparison with those with a bachelor degree. This could be explained by the longer experience years of the diploma nurses, which would certainly help them to acquire better leadership competencies. A similar positive progress in leadership skills over experience years was observed among charge nurses in a study in the United States (Krugman et al, 2013).

In support of this foregoing explanation, the current study identified significant positive correlations between the total experience years and the scores of idealized influence (behavior) domain of transformational leadership and the contingent reward domain of the transactional style, while the correlation with the laisser-faire leadership score was negative. Moreover, the total experience years had significant positive correlations with head nurses' scores of leadership outcomes. In agreement with this, Fischer (2016) in a conceptual study in the United States clarified that transformational leadership is a set of competencies that can be learned and gained.

\section{Conclusions:}

The study concludes that head nurses in the study settings have a high level of assertiveness. They mostly use the transformational and transactional leadership styles. Their level of assertiveness is significantly and positively influenced by their total experience years, whereas their age has a negative effect. Meanwhile, the scores of the transformational leadership domains of idealized influence (attributed), idealized 
influence (behavior), and inspirational motivation have positive effects on their assertiveness, while the laisser-faire leadership has a negative impact on it.

\section{Recommendation:}

- The attendance of training in leadership and in assertiveness should be set as prerequisites for promotion to the position of a nurse manager or leader.

- Further study is proposed to assess the effectiveness of training in assertiveness on nurse managers' proper use of leadership styles.

\section{References:}

Abdel- Khalek M. (2010): Level of assertiveness and nursing performance; unpublished Master degree, thesis in nursing administration, faculty of nursing, Cairo University, pp. 4-10

Abdel-Aleem M. (2007): Factors affecting assertiveness among head nurses and staff nurses. Unpublished Master degree, thesis in nursing administration, faculty of nursing, Suez Canal University, pp.74-76.

Alshahrani M.F.M., and Baig L.A. (2016): Effect of Leadership Styles on Job Satisfaction Among Critical Care Nurses in Aseer, Saudi Arabia. J Coll Physicians Surg Pak.;26(5):366-70. doi: 2316.

Ames D. (2009): Pushing up to a point: Assertiveness and effectiveness in leadership and interpersonal dynamics Research in Organizational Behavior; 29: 111-133

Arnold E.C., and Boggs K.U. (2015): Interpersonal Relationships - E-Book:
Professional Communication Skills for Nurses. Elsevier Health Sciences;576, $0323328571,9780323328579$.

Barkhordari- Sharifabad M., Ashktorab T., and Atashzadeh- Shoorideh F. (2017): Ethical leadership outcomes in nursing. Nurs Ethics.; 969733016687157.doi:10.1177/ 0969733016687157.

Cabe C., and Timmins F. (2013): Teaching assertiveness to undergraduate nursing students. Available at: http://www. nurseeducationinpractice.com/article/S1 471-5953(02)000 79- 3/abstract

Deena D.T. (2015): Mental Health Nursing. India: Elsevier, p. 278

Developing-Assertiveness Traits and Management (2016): Retrieved on May 172016 at: http://www.exforsys. com/ careercenter/ assertive/ traits-of-anassertive-manager.html

El Amouri S., and O'Neill S. (2014): Leadership style and culturally competent care: Nurse leaders' views of their practice in the multicultural care settings of the United Arab Emirates. Contemp Nurse.; 20:3552-3573.

Ellis R.J., and Love C. (2010): Managing and coordinating nursing care $\left(3^{\text {rd }} \mathrm{Ed}\right)$. London, Philadelphia: Lippincott, pp. 515-522.

Fischer S.A. (2016): Transformational leadership in nursing: a concept analysis. J Adv Nurs.;72(11):26442653. doi: 10.1111/jan.13049. Epub 2016 Jul 26.

Foley V., Myrick F., and Yonge O. (2012): Generational clashpoints in nursing preceptorship. J Nurs Educ.;51(10):55662. doi: 10.3928/01484834-2012082004. Epub 2012 Aug 20. 
Gøtzsche-Astrup O., Jakobsen J., and Furnham A. (2016): The higher you climb: Dark side personality and job level. Scand J Psychol.;57(6):535-541. doi: 10.1111/sjop.12305. Epub $2016 \mathrm{Jul}$ 14.

Green J. (2016): Enhancing assertiveness in district nurse specialist practice. $\mathrm{Br} \mathrm{J}$ Community Nurs.;21(8):400-3. doi: 10.12968/bjen.2016.21.8.400.

Jodar I., Solà G., Gené I., Badia J., Hito P.D., Osaba M.A., and Del Val García J.L. (2016): Self-perception of leadership styles and behaviour in primary health care. BMC Health Serv Res.;16(1):572.

Khalil D. (2011): Assertive behavior among nursing working in critical units at ain shims university hospital. Master degree, thesis in nursing psychiatric, faculty of nursing, Ain shims University, pp. 66-77

Krugman M., Heggem L., Kinney L.J., and Frueh M. (2013): Longitudinal charge nurse leadership development and evaluation. J Nurs Adm.;43(9):438-46. doi: 10.1097/NNA. 0b013e3182a23b26

Lievens I., and Vlerick P. (2014): Transformational leadership and safety performance among nurses: the mediating role of knowledge-related job characteristics. J Adv Nurs;70(3):65161. doi: 10.1111/jan.12229. Epub 2013 Aug 26.

Lyndon A., Sexton J.B., Simpson K.R., Rosenstein A., Lee K.A., and Wachter R.M. (2012): Predictors of likelihood of speaking up about safety concerns in labour and delivery. BMJ Qual Saf.;21(9):791-9. doi: 10.1136/bmjqs2010-050211.

Marshall E.S. (2011): Transformational leadership in nursing: From expert clinician to influential leader. New
York, NY: Springer Publishing Company, LLC

Melin-Johansson C., Palmqvist R., and Rönnberg L. (2017): Clinical intuition in the nursing process and decisionmaking - A mixed studies review. J Clin Nurs.. doi: 10.1111/jocn.13814.

Morsiani G., Bagnasco A., and Sasso L. (2017): How staff nurses perceive the impact of nurse managers' leadership style in terms of job satisfaction: a mixed method study. J Nurs Manag.;25(2):119-128. doi: 10.1111/jonm.12448. Epub 2016 Dec 5.

Reese J., Simmons R., and Barnard J. (2016): Assertion Practices and Beliefs Among Nurses and Physicians on an Inpatient Pediatric Medical Unit. Hosp Pediatr.;6(5):275-81.

Ross E.J., Fitzpatrick J.J., Click E.R., Krouse H.J., and Clavelle J.T. (2014): Transformational leadership practices of nurse leaders in professional nursing associations. J Nurs Adm.;44(4):201-6. doi: 10.1097/NNA.000000000 0000058 .

Rowe W.G. (2014): Cases in Leadership. Thousand Oaks, CA: Sage Publications Leadership Management: Principles, Models and Theories, p. 317

Shaker S., and Khalil S. (2014): Relationship between assertiveness and decision making abilities among nurses managers at university hospital Master degree, in Nursing administration, Faculty of Nursing, Ain Shams University, pp. 84:87-91:100.

Stojčić Ž., Perković L., Stašević I., Stojčić N., and Ropac D. (2014): [Relationship of perception conflict and assertiveness in nurses]. Acta Med Croatica.;68(3):259-71. 
Warland J., McKellar L., and Diaz M. (2014): Assertiveness training for undergraduate midwifery students. Nurse Educ Pract.;14(6):752-6. doi: 10.1016/j.nepr.2014.09.006. Epub 2014 Oct 2.

Weiss S.A., and Tappe R.M. (2014): .Essentials of Nursing Leadership and
Management. $6^{\text {th }}$ Edition., Philadelphia: Davis Company.

Weng R.H., Huang C.Y., Chen L.M., Chang L.Y. (2015): Exploring the impact of transformational leadership on nurse innovation behaviour: a cross-sectional study. J Nurs Manag.; 23(4):427-39. doi: 10.1111/jonm.12149. Epub 2013 Sep 